\title{
0 Contextualismo Linguístico na História do Pensamento Político: Quentin Skinner e o Debate Metodológico Contemporâneo*
}

\author{
Ricardo Silva
}

Professor associado do Departamento de Sociologia e Ciência Política da Universidade Federal de Santa Catarina (UFSC). E-mail: <rsilva@cfh.ufsc.br>

\begin{abstract}
$\mathrm{N}$ as últimas três ou quatro décadas, poucas abordagens influenciaram tão amplamente a metodologia e a prática da história do pensamento político do que a modalidade de "contextualismo linguístico" propugnada pela chamada "Escola de Cambridge". Independentemente da avaliação que se faça de tal influência, o fato é que, desde os anos 1960 - época em que John Pocock (1962), John Dunn (1968) e Quentin Skinner (1966; 1969) publicaram seus primeiros ensaios metodológicos - o contextualismo linguístico tem sido objeto de incessante interesse, tanto de adeptos quanto de críticos. Um importante resultado de todo esse interesse foi a constituição de um amplo campo de debates sobre problemas cruciais de teoria e método que, originários do campo da história intelectual, vêm se revelando pertinentes a várias outras disciplinas das humanidades, como, de resto, indica a participação de teóricos da política, filósofos, críticos literários e sociólogos nos diálogos e disputas.
\end{abstract}

\footnotetext{
* A maior parte da pesquisa que serviu de base para o presente artigo realizou-se durante meu estágio pós-doutoral junto ao Departamento de Ciência Política da Universidade da Califórnia (Berkeley), entre agosto de 2005 e julho de 2006. Sou grato à Coordenação de Aperfeiçoamento de Pessoal de Nível Superior (Capes) pelo suporte financeiro e ao professor Mark Bevir pela interlocução ao longo de minha estadia em Berkeley. Uma versão anterior do texto foi apresentada em sessão da área temática de Teoria Política no V Encontro da Associação Brasileira de Ciência Política (ABCP), realizado em Belo Horizonte, em julho de 2006. As traduções das citações da bibliografia em língua estrangeira são de minha autoria.
}

DADOS - Revista de Ciências Sociais, Rio de Janeiro, vol. 53, n-2, 2010, pp. 299 a 335. 
Este artigo destina-se a compreender e analisar o referido campo de debates, detendo-se nas prescrições metodológicas de Quentin Skinner e nas mais recorrentes objeções levantadas contra tais prescrições. O principal motivo para atribuir a Skinner um lugar de destaque na reconstituição das discussões em torno do contextualismo linguístico refere-se ao fato de que, entre os historiadores de Cambridge, foi ele quem mais obstinadamente dedicou-se à dupla tarefa de invectivar contra as abordagens concorrentes e formalizar a metodologia contextualista. Em consequência disso, é contra Skinner que a maior parte dos críticos do contextualismo linguístico tem dirigido suas baterias. Ademais, embora geralmente os críticos de Skinner estendam suas conclusões às proposições dos demais membros da Escola de Cambridge, com muita frequência tal procedimento passa ao largo de pronunciadas discordâncias entre os dois principais expoentes do grupo $^{1}$.

Convém ressaltar que a análise a seguir deter-se-á exclusivamente à dimensão metodológica da obra de Skinner. Embora o autor se notabilize por volumosa produção substantiva no campo da história do pensamento político, não me ocuparei, aqui, desta dimensão de sua obra ${ }^{2}$. Evitarei o impulso de avaliar o método de Skinner à luz de suas realizações práticas como historiador por considerar que qualquer obra substantiva complexa realiza, ao mesmo tempo, mais e menos do que prescreve o método que a inspirou. Realiza mais porque há fatores não controlados pelas prescrições metodológicas que influenciam o resultado de uma investigação, tais como o acesso a recursos materiais e institucionais, a "sorte" na descoberta de documentos relevantes, ou características idiossincráticas, como a energia individual e a criatividade dos pesquisadores; e realiza menos porque toda metodologia "exagera" em suas prescrições, sugerindo um "ideal" procedimental que jamais se efetiva integralmente.

Primeiramente, apresentarei as linhas gerais da abordagem associada à Escola de Cambridge no contexto do surgimento de suas primeiras formulações. Em seguida, delinearei os aspectos centrais do método proposto por Skinner, revelando a articulação de seus conceitos-chave e as fontes de inspiração do autor. Feito esse esboço, passarei a examinar as objeções às prescrições de Skinner, paralelamente às tentativas do autor de reagir a tais objeções. Examinarei, primeiro, os ataques à dimensão epistemológica da metodologia de Skinner - ora tratada como positivista, ora como relativista - para, em seguida, avaliar as 
críticas ao compromisso do autor com uma perspectiva intencionalista na história intelectual. Encerro examinando as críticas que apresentam o historiador de Cambridge como advogado de uma atitude "antiquarista" nos estudos históricos, críticas que, a meu ver, o obrigam a procurar uma justificativa plausível para a relevância contemporânea do estudo do passado. Veremos que as tentativas de defender-se da acusação de antiquarismo têm conduzido Skinner para posições distantes de suas postulações metodológicas originais.

\section{EM BUSCA DO "GENUINAMENTE HISTÓRICO"}

A primeira investida dos contextualistas de Cambridge contra os estilos convencionais de história das ideias políticas partiu de Peter Laslett, historiador que exerceu grande influência nos estudos iniciais de Pocock, Skinner e Dunn³. Em 1956, Laslett declarou, com evidente intenção polêmica, que "no momento, [...] a filosofia política está morta" (1956:vii). A declaração surgia num contexto em que o tratamento filosófico das ideias políticas era questionado por uma série de outras abordagens. As novas teorias concernentes à natureza da linguagem, as alternativas da ciência política behaviorista e das abordagens sociológicas da política - dentre as quais o marxismo - passaram a representar sérios desafios para a filosofia política e a historiografia caracterizadas pela busca da dimensão intemporal das ideias dos grandes pensadores. Em sua famosa edição crítica dos Dois Tratados sobre o Governo, Laslett, numa indicação do procedimento contextualista, afirmava que "nosso primeiro propósito deve ser um modesto exercício de historiador-estabelecer os textos de Locke como ele gostaria que fossem lidos, fixá-los em seu contexto histórico, no próprio contexto de Locke" (1960:4).

Embora a abordagem contextualista tenha começado a ser posta em prática ao longo da década de 1950, foi somente na década seguinte que apareceram suas formulações metodológicas mais declaradas. Em 1962, Pocock publicou um artigo chamando a atenção para a necessidade de se resgatar a história do pensamento político do domínio do tratamento exclusivamente filosófico dos textos clássicos. Ao diagnosticar a tendência de a história do pensamento político transformar-se em filosofia, criticava a preocupação unilateral com o estabelecimento da "coerência racional" das ideias dos autores do passado, sem levarem-se em consideração os diversos "níveis de abstração" em que o 
pensamento político surge na história. Argumentava que o historiador convencional

[...] não é capaz de adotar um método que reconheça que há diferentes níveis de abstração em que o pensamento se expressa e diferentes graus de coerência racional pelos quais ele pode ser explicado; menos ainda um método que permita discriminar entre tais níveis como matéria de investigação histórica. Ele é ainda prisioneiro de um método que o condena a explicar o pensamento político somente na medida em que este pode ser apresentado como teoria política sistemática ou filosofia. (Pocock, 1962:189)

Para Pocock, esse tipo de orientação metodológica impossibilitava a compreensão das conexões entre pensamento e comportamento político em dado momento histórico. O autor não questionava a legitimidade da história do pensamento como história das abstrações das tradições intelectuais, porém a completa desconexão deste tipo de narrativa com a história das expressões menos abstratas do pensamento, aquelas que guardam uma relação mais imediata com o comportamento dos agentes. Ao advogar uma certa divisão do trabalho entre o historiador das tradições dos textos canônicos e o historiador das linguagens diretamente associadas à atividade política, Pocock também sugere que o trabalho do primeiro tende a se beneficiar do trabalho do segundo. Uma vez que o historiador se familiariza "com as diferentes linguagens de discussão que estavam em uso, e com os diferentes níveis de abstração que elas normalmente implicavam, ele será capaz de certificar-se em que linguagem e em que nível dada controvérsia foi conduzida ou dado pensador desenvolveu suas ideias" (ibid.:200).

As orientações metodológicas esboçadas por Pocock reapareceriam de forma ainda mais enfática em um artigo de John Dunn, publicado originalmente em 1968. Dunn continuava insistindo na necessidade de se estudar a história das ideias como a "história de uma atividade", e mostrava-se mais resoluto que Pocock a respeito da convicção de que "é íntima a conexão entre uma abordagem filosófica adequada às noções sustentadas por um indivíduo no passado e uma acurada abordagem histórica destas noções", uma vez que "tanto a especificidade histórica quanto a sofisticação filosófica serão mais bem alcançadas se ambas forem perseguidas em conjunto" (Dunn, 1968:86). Desagradava, também, a Dunn a tendência de se escrever a história das ideias como a história de "ficções", de "construções racionais fora do processo de pensamento dos indivíduos" (ibid.:87), passando-se ao largo da 
dimensão humana da atividade de pensar, caracterizada por sua "incompletude, incoerência, instabilidade" e pelo esforço humano para superar tais características (ibid.:88). Como toda atividade humana, a atividade discursiva ocorre num contexto que simultaneamente a restringe e capacita. Porém, como definir o contexto relevante a ser reconstituído para a compreensão de determinado ato linguístico? Uma vez que "o problema da interpretação é sempre o problema do fechamento do contexto", qual o critério à disposição do intérprete para essa operação de fechamento? Em chave collingwoodiana, Dunn responde que "o que realmente fecha o contexto é a intenção (e, muito mais amplamente, as experiências) do orador" (ibid.: 98). Ou seja, a reconstituição do contexto linguístico de um autor é relevante na medida em que nos ajuda a recuperar a intenção do autor ao efetuar determinada ação. Se escrever é "fazer coisas com palavras", o objetivo central do historiador é revelar o que um determinado autor "estava fazendo" ao escrever o que escreveu (ibid.:93).

Coube a Quentin Skinner a elaboração mais sistemática do encontro da filosofia da história de Collingwood com o aparelho analítico da filosofia da linguagem ordinária. A exemplo do que se observou em Laslett, Pocock e Dunn, também em Skinner a afirmação da metodologia contextualista surge de par com a crítica às abordagens convencionais. Já em 1966, o autor investia contra o alvo preferido dos historiadores de Cambridge: a história das grandes ideias retiradas de seus contextos de origem. Ao mesmo tempo que argumentava contra a suposição de infalível "coerência" dos grandes pensadores, Skinner criticava o que considerava uma vaga noção de "influência", mediante a qual se compunha um tipo de narrativa em que as grandes ideias de grandes autores explicavam-se pela influência recebida de outras grandes ideias de outros grandes autores. Esse estilo de história do pensamento político como o registro do diálogo transcontextual entre os pensadores clássicos ignorava que "as qualidades de inteligência e apresentação que fazem de um autor a melhor ilustração em um cenário filosófico farão dele a pior ilustração num cenário histórico" (Skinner, 1966:213).

Logo em seguida, em tom ainda mais provocativo, Skinner escreve um ensaio intitulado "On the Unimportance of the Great Texts to the History", publicado depois com o título "Meaning and Understanding in the History of Ideas ${ }^{4}$. A maior parte do beligerante texto de 50 páginas era dedicada à refutação das abordagens concorrentes na história das ideias. Suas críticas mais extensas e enfáticas eram dirigidas contra o 
que designava como abordagem "textualista" 5 . O autor censurava o procedimento padrão do textualismo, que consistiria, em suas expressões mais caricaturais, em "ler e reler" determinado texto até se chegar a uma compreensão correta de seu significado. O pressuposto deste procedimento é que o texto é autônomo em relação ao contexto de seu surgimento, o que é consistente com a crença de que determinados textos (aqueles dignos do interesse do historiador) contêm "elementos intemporais", "ideias universais" e "uma sabedoria sem tempo" de "aplicação universal" (Skinner, 1969:4).

Para Skinner, a abordagem dos textos clássicos por meio desse procedimento tendia a gerar não história, mas "mitologias". Dentre as principais mitologias denunciadas por Skinner encontram-se as seguintes:

a) mitologia da doutrina (ibid.:7-16) - os enunciados dos autores clássicos, mesmo que esparsos e ocasionais, são forçosa e sistematicamente enquadrados em "doutrinas", construções típico-ideais do próprio historiador, mas que este atribui ao universo das crenças do autor estudado;

b) mitologia da coerência (ibid.: 16-22) - presume-se que o autor construiu (ou ao menos tentou construir) sistemas intelectuais fechados, em que todos os seus enunciados mantêm uma relação de coerência com os demais, o que impede o historiador de perceber as contradições entre os enunciados de um autor (usualmente apresentadas, quando percebidas, como "aparentes contradições") ou suas mudanças de concepção a respeito de certos temas;

c) mitologia da prolepse (ibid.:22-24) - confunde-se o significado dos enunciados para o historiador com o significado para o autor, sendo este último negligenciado. O enunciado só revelaria seu significado no presente, conclusão que repousa sobre o contestável pressuposto teleológico de que a ação linguística precisaria esperar pelo futuro para revelar-se totalmente;

d) mitologia do paroquialismo (ibid.:24-28) - seguindo padrões atuais de discriminação e classificação, o historiador, em face de um mundo passado que lhe é estranho, constroi uma identidade entre o universo mental do autor do passado e o seu próprio universo atual de crenças, produzindo uma falsa familiaridade entre culturas muito distintas.

A característica comum a todas essas "mitologias" seria a produção de interpretações "anacrônicas", mediante as quais são atribuídas a de- 
terminado autor ideias e intenções cujos recursos linguístico-expressivos eram ainda indisponíveis no contexto histórico do proferimento.

Feita a invectiva contra a abordagem "textualista", Skinner dirige suas baterias contra os tipos de contextualismo que privilegiam o contexto social, em vez do contexto linguístico, nas estratégias de compreensão de determinado texto. O contextualismo sociológico, tanto em sua vertente marxista quanto "namierista" ${ }^{6}$, repousaria sobre a confusão entre dois procedimentos intelectuais inteiramente distintos: a determinação causal de uma ideia e a sua compreensão propriamente dita. Não se trata de negar que as condições econômicas e sociais das sociedades em que os autores produzem seus textos possam ser apresentadas como antecedentes causais contingentemente conectados com o conteúdo do texto a ser compreendido. A determinação das causas externas à ação linguística seria um procedimento relevante para a explicação da referida ação. Todavia, isso estaria muito longe da exagerada e errônea presunção de que "as ideias de um dado texto devem ser compreendidas em termos de seu contexto social" (Skinner, 1969:43, ênfase no original). A compreensão de uma ideia enquanto ação linguística significa algo mais do que sua explicação causal. Ao fixar-se exclusivamente na determinação causal das ideias, perseguindo as conexões externas e contingentes das ideias com fenômenos não linguísticos, parte da literatura contextualista reforçaria uma visão em que o papel das ideias na sociedade e na política é desprovido de autonomia e eficácia. As ideias não seriam mais do que epifenômenos, expressões ou reflexos de uma "realidade material" ontologicamente anterior ao - e determinante do - mundo da linguagem. Além de outras fragilidades, os métodos derivados desta concepção estariam desarmados para explicar, por exemplo, o fato de um mesmo contexto social ser capaz de abrigar, simultaneamente, ideias que expressam os mais variados conteúdos linguísticos e valorativos, além de autores que manifestam as mais diversas intenções (ibid.:47).

Para Skinner, a alternativa tanto ao textualismo quanto ao contextualismo sociológico reside na recuperação da tradição intencionalista da filosofia da história e na aplicação de seus princípios na elaboração de uma metodologia voltada para a interpretação de textos. Em diversas ocasiões, o autor explicita o papel central da filosofia da história de R. G. Collingwood no movimento de afirmação do contextualismo linguístico ${ }^{7}$. Collingwood partia do princípio de que somente conhecendo a si próprio poderia o ser humano ter um conhecimento satisfatório 
de outras coisas, sendo que tal conhecimento de si próprio refere-se ao "conhecimento de suas faculdades de cognição, do seu pensamento ou de seu entendimento ou de sua razão" (Collingwood, s.d.:257). Ao transferir esse princípio epistemológico para sua teoria da investigação histórica, Collingwood afirma que "toda história é história do pensamento" (ibid.:268). Toda ação historicamente significativa deve ser reconstituída tendo em vista o pensamento do agente que a efetuou. Collingwood distingue entre os aspectos externos ("eventos") e os aspectos internos de um acontecimento ${ }^{8}$. Embora possa começar pela descoberta do exterior de um acontecimento, o trabalho do historiador só irá completar-se na medida em que ele consiga relacionar o evento descoberto com o interior do acontecimento. Para isso, o historiador "tem de recordar-se sempre de que o acontecimento foi uma ação, e que sua tarefa essencial é meter-se ele próprio no interior dessa ação, é discernir o pensamento do seu agente" (ibid.:267). Collingwood esclarece, ainda, que essa tarefa não se reduz a um procedimento acrítico e inteiramente descritivo - o que, de resto, é impossível - do pensamento dos agentes do passado. Trata-se, sim, de um procedimento crítico pelo qual o historiador "repensa" ou "reconstitui" (re-enact) o pensamento do passado e, ao fazê-lo, "critica-o, forma um juízo próprio sobre seu valor, corrige erros que consiga discernir nele" (ibid.:268-269).

Embora Skinner tenha manifestado sua insatisfação com a "infeliz frase" em que Collingwood afirmava que o intérprete deveria "repensar" o pensamento do passado ${ }^{9}$, não resta dúvida de que a arquitetura de seu projeto metodológico repousa sobre fundações collingwoodianas. É o historicismo de Collingwood que está subjacente à convicção de Skinner de que a história do pensamento político deve ater-se ao contexto imediato da produção dos textos cujos significados o historiador pretende compreender. A inexistência de "ideias perenes" na história da teoria política decorre do fato de que todo autor, por mais inovador que seja, está irremediavelmente situado num universo de convenções linguísticas que são, ao menos em parte, exclusivas do contexto de enunciação.

Se Collingwood é a principal influência na visão de Skinner sobre a natureza do conhecimento histórico, é a filosofia do segundo Wittgenstein que permite ao historiador de Cambridge a elaboração da crucial noção de significado (meaning). Skinner parte da célebre formulação de Wittgenstein de que "palavras também são atos" (Wittgenstein, 1958:146), enquanto procura elaborar o princípio pragmático de que o 
significado dos atos linguísticos depende de seus usos em determinados jogos de linguagem. Era natural que Skinner recorresse às contribuições dos filósofos da linguagem que mobilizaram a noção wittgensteiniana de significado para a elaboração da teoria dos atos de fala (speech acts theory). Dentre tais contribuições, Skinner destaca as de J. L. Austin, esboçadas no volume postumamente publicado sob o sugestivo título de How To Do Things with Words. Austin desafiava a crença de que os enunciados linguísticos devem ser estudados exclusivamente a partir de suas funções "constatativas", ou seja, a partir do que representam como descrição (que pode ser avaliada como verdadeira ou falsa) de determinado estado de coisas. Gramáticos e filósofos desta orientação convencional desconsiderariam o fato de que, além das sentenças constatativas, há toda uma classe de enunciados linguísticos dotados de uma força que não pode ser julgada conforme os parâmetros de verdade ou falsidade. Tais enunciados são definidos como "performativos", justamente para indicar que "a emissão de um enunciado é a efetuação de uma ação" (Austin, 1975:6).

Austin distingue três dimensões dos atos de fala: a dimensão locucionária, relativa ao conteúdo proposicional do proferimento e manifesta no ato de dizer (of saying) algo; a dimensão ilocucionária, relativa ao que o agente está fazendo ao dizer (in saying) algo; e a dimensão perlocucionária, relativa aos efeitos produzidos pelo ato de fala na audiência, aquilo que ocorre por se dizer (by saying) algo (ibid.:94-120). O esforço do autor consiste em salientar a dimensão ilocucionária dos atos de fala, pois é nela que se concentra a característica negligenciada pelas teorias convencionais do significado, as quais se atêm, principalmente, à dimensão locucionária e, em menor medida, à dimensão perlocucionária das sentenças. É na dimensão ilocucionária de um proferimento que reside sua força enquanto ação, força que se identifica com a intenção do agente ao dizer algo em determinado contexto de convenções linguísticas. Se, por exemplo, a intenção de alertar alguém pode ser reconhecida como uma intenção possível no âmbito das convenções disponíveis aos agentes na ocasião da emissão do ato de fala, pouco importa o fato de que a intenção do emissor resulte nos efeitos desejados no estado de compreensão do receptor, uma vez que a força ilocucionária de um ato de fala não se identifica com seus efeitos perlocucionários (ibid.:110).

A taxonomia dos atos de fala elaborada por Austin é mobilizada sistematicamente por Skinner. Num primeiro momento, Skinner estabelece 
uma equalização entre a compreensão do significado de um texto e a reconstituição da intenção ilocucionária do autor. Compreender o significado de um texto histórico seria o mesmo que revelar o que o autor do texto estava fazendo ao escrevê-lo. Para isso, dever-se-ia estudar o modo como a intenção do autor se inscreve no contexto de convenções linguísticas em que o texto foi produzido (Skinner, 1969:49). Em momento posterior, em face das críticas ao que se denunciava uma noção reducionista e excessivamente estrita de significado, Skinner passa a conceder que é possível distinguir entre três diferentes sentidos do termo. Primeiramente, o autor refere-se ao meaning 1, significado que está em questão quando se faz uma pergunta do tipo: "O que as palavras, ou específicas palavras ou sentenças significam nesta obra?" (Skinner, 1972:396). Este tipo de significado é capturado mediante o estudo da semântica e da sintaxe do texto, com o recurso ao nosso conhecimento convencional da linguagem codificado em livros de gramática e dicionários. Em seguida, Skinner refere-se ao meaning 2, associado à questão: “O que isto significa para mim?" (ibid.:396). Trata-se, aqui, de entender o texto a partir de seus efeitos nos leitores, o que pode dar surgimento a uma história da recepção dos textos enquanto fenômenos que transcendem o contexto e o momento de sua produção original. Por último, há o que Skinner denomina meaning 3, que está em jogo quando se pergunta: "O que o autor quis dizer com o que ele disse nesta obra?" (ibid.:397).

Não obstante a concessão dessas distinções, Skinner reafirma o ponto central de sua metodologia ao defender a posição de que uma interpretação comprometida com a recuperação do significado histórico dos textos do passado exige que o historiador se concentre na terceira concepção de significado mencionada acima, a única conectada com a intenção autoral incorporada na escritura dos textos; e conectada a ponto de se poder falar em uma "equivalência" entre significado e intenção. Conforme o autor,

quando nós retornamos ao meaning 3, parece possível estabelecer a conexão mais próxima possível entre a intenção do autor e o significado do que ele escreve. Por isso, parece que um conhecimento da intenção do autor ao escrever, no sentido que procurei isolar, não é meramente relevante, mas é realmente equivalente ao conhecimento do meaning 3 do que ele escreve. (ibid.:404, ênfases no original)

Neste ponto, Skinner sugere, ainda, uma outra distinção estratégica para a defesa de sua metodologia. Uma coisa seria falar das intenções 
de determinado autor incorporadas naquilo que escreveu e nas circunstâncias em que o fez. Outra, inteiramente distinta, seria considerar os "motivos" que conduziram o autor à escrita do texto. Os motivos de um autor podem ser examinados como causas externas do enunciado linguístico cristalizado no texto, causas que se conectam apenas de modo contingente com tal enunciado. Por outro lado, sua intenção ao escrever o texto, intenção incorporada na própria ação linguística, não exterior a ela, "deve ser tratada como uma condição necessária para que se possa interpretar o meaning 3 de suas obras" (ibid.:406) ${ }^{10}$. Com base nessa distinção, o autor defende a possibilidade de uma explicação não causal de textos históricos. Este tipo de explicação, estranho à tradição "naturalista" de explicação da ação social, teria como procedimento padrão a redescrição da intenção ilocucionária do autor do texto (Skinner, 1971:13; 1988a: 96).

Mas não é somente contra o naturalismo que a distinção entre motivos e intenções é mobilizada por Skinner. Ela também serve a seu esforço para afastar-se do tipo de hermenêutica romântica que identifica a recuperação da intenção autoral com uma espécie de mergulho do intérprete na mens auctoris do passado. Skinner busca evitar o subjetivismo subjacente a esta vertente intencionalista chamando a atenção para o caráter "publicamente apreensível" das intenções autorais (Skinner, 2002a:120 ${ }^{11}$. A compreensão do significado de um texto não requer do intérprete a misteriosa habilidade de penetrar na mente do autor para revelar seus estados psíquicos interiorizados na forma de desejos, planos ou desígnios. Requer, sim, o procedimento muito mais prosaico embora necessariamente paciente e erudito - de situar o texto em questão no contexto de convenções linguísticas e sociais que governam o tratamento dos temas e problemas dos quais o texto se ocupa. Conforme o próprio autor,

de modo a recuperar tais intenções, é normalmente tido como essencial cercar o texto dado com o contexto apropriado de pressuposições e convenções a partir do qual o significado exato intencionado pelo autor pode ser decodificado. Isto acarreta a conclusão crucial de que o conhecimento das pressuposições e convenções deve ser essencial para a compreensão do significado do texto. (Skinner, 1975:216)

A ênfase nas convenções linguísticas para a reconstituição das intenções autorais parte do pressuposto de que todo autor - especialmente o autor de textos políticos - está envolvido em um ato de comunicação quando escreve ou publica seu texto. De modo a ser compreendido pe- 
los leitores, não lhe resta outra alternativa a não ser mobilizar, em seu discurso, os padrões convencionais de comunicação acerca dos temas para os quais deseja chamar a atenção. Isso é válido não somente para os casos em que o autor tem a intenção de seguir e reforçar as convenções existentes, mas, também, para aqueles casos em que sua intenção é criticar ou subverter tais convenções. Mesmo os mais revolucionários e inovadores pensadores, aqueles desejosos de convencer seus leitores da necessidade de alteração do significado de termos e conceitos de uso corrente, ou do abandono de seus usos em favor da aquisição de novos termos e conceitos, precisam recorrer à linguagem convencional, ou seus esforços de comunicação serão inócuos (Skinner, 1970:135).

Nossa intenção, até aqui, foi chamar a atenção para os suportes mais estáveis da metodologia skinneriana: seu historicismo radical (a visão do passado como um "país estrangeiro"), e sua confiança na recuperação da singularidade das ideias do passado por meio do estudo dos textos históricos enquanto registros da ação intencional de seus autores.

\section{CRÍTICAS E OBJEÇÕES}

No fim da década de 1980, Skinner começa seu mais extenso texto de resposta a seus críticos, confessando-se, em tom irônico, "perplexo por aprender", que é, ao mesmo tempo, "um idealista, um materialista, um positivista, um relativista, um antiquário, um historicista, e um mero metodólogo com nada de substancial a dizer" (Skinner, 1988c:231). Embora sua lista esteja incompleta, pois há ainda os que, mirando em seu pensamento político, o rotulem de "conservador" (Shapiro, 1982; Keane, 1988), "pós-moderno" (Lamb, 2004), "ideólogo do republicanismo" (Urbinati, 2005), "ironista liberal" (Mandell, 2000:122) ou "republicano romântico" (Perreau-Saussine, 2007:121), ela nos dá uma ideia da multiplicidade de direções das reações às suas ideias. Ao longo de mais de três décadas presenciando um contínuo ataque às suas posições, Skinner tem se empenhado em responder às críticas que lhe têm sido dirigidas, quer mediante revisões e reedições de seus ensaios originais, quer pela produção de textos concebidos especificamente para rebater as críticas, o que tem feito do autor uma espécie de "alvo móvel", conforme observou um de seus comentadores (Lamb, 2004:424). 
A despeito da multiplicidade de perspectivas e da variedade de temas que emergem do conjunto das críticas ao contextualismo linguístico, em geral, e à obra de Skinner, em particular, há uma recorrência de determinadas objeções. Para efeitos de organização de nossa apresentação do debate, podemos classificar tais objeções em três ordens analiticamente diferenciáveis, mas interdependentes, de argumentos: a) as objeções ao historicismo radical de Skinner, presentes na generalizada acusação de que sua teoria da história desemboca num "antiquarismo" improdutivo para o entendimento dos dilemas do presente; $b$ ) as objeções à teoria intencionalista do significado de textos como expressões de atos linguísticos; c) as objeções ao estatuto epistemológico da metodologia skinneriana, ora acusada de relativista, ora de objetivista (ou mesmo positivista), ora de nem mesmo ser uma metodologia.

\section{Verdade e Método}

Comecemos examinando o terceiro tipo de objeções, aquele dirigido contra os pressupostos epistemológicos da metodologia contextualista. Aqui, não deixa de ter certa razão Skinner ao declarar sua perplexidade diante dos diferentes (e contraditórios) rótulos com os quais seus críticos se referem às suas ideias. Que sentido há em ser acusado, ao mesmo tempo, de positivista e de idealista, de objetivista e de relativista, de adotar uma espécie de "imperialismo" metodológico e de não ter metodologia alguma? ${ }^{12}$

A orientação pretensamente positivista da metodologia proposta por Skinner tem sido denunciada como consequência da enfática recomendação do autor para que o historiador das ideias dedique-se a estudar o passado nos próprios termos do passado. Conforme muitos de seus críticos, tal recomendação teria como pressuposto a crença na possibilidade de uma radical separação entre os valores sustentados pelo intérprete situado no presente e aqueles pertencentes aos pensadores do passado, os quais o intérprete toma como objeto de investigação. Femia, por exemplo, afirma que tal recomendação conforma-se à "teoria positivista do conhecimento, que repousa sobre uma completa disjunção entre sujeito e objeto". O processo de recepção dos "dados" do passado é "passivo: o mundo externo dos fatos 'fala por si próprio', e o conhecimento humano apenas traduz, ou reflete, o que tem lugar no mundo primário das coisas 'dadas'”' (Femia, 1988:168). A mesma linha de ataque é expressa por Seidman, que considera que este "espírito positivista desinteressado" leva Skinner a promover uma visão "objeti- 
vista", em que "o intérprete pode exercer suficiente autocontrole metodológico para evitar a intrusão de interesses e valores do presente na reconstrução objetiva do passado" (Seidman, 1983:84). Keane, por sua vez, elabora essa objeção argumentando que "o antiquado positivismo da nova história de Skinner" ignora que a interpretação do passado só é possível porque o intérprete é sempre um participante do universo de comunicação que ele deseja compreender. A pressuposição de Skinner "de pesquisadores desinteressados que estão separados de seu objeto de interpretação deixa de levar em conta que, de modo a ser possível qualquer interpretação, ambos [intérprete e objeto] já precisam estar reunidos em e através de um ponto de partida linguístico" (Keane, 1988:210-211, ênfases no original).

Em textos mais recentes, Skinner desenvolve argumentos destinados a distanciar-se do rótulo de positivista. Afinal, ele prefere ver-se na companhia de autores que, a partir dos anos 1960, iniciaram um sistemático ataque ao positivismo e ao objetivismo naturalista prevalecente nas ciências humanas. Sua estadia de quatro anos (1976-1979) no Instituto de Estudos Avançados de Princeton permitiu-lhe estreita colaboração com intelectuais como Thomas Kuhn, Clifford Geertz, Albert Hirschman, Michel Walzer, Joan Scott e muitos outros, unidos no espírito comum de rejeição da herança positivista ${ }^{13}$. Em sintonia com esses autores, Skinner argumenta que a suposição da existência de "fatos puros" à disposição do escrutínio dos cientistas sociais e historiadores consiste em um grave erro epistemológico. Não há acesso privilegiado a "fatos indisputáveis", pois as percepções que temos das coisas são, em última análise, "interpretações". Em suma, nosso acesso aos "fatos" e nossa ideia do que é racional são aspectos irremediavelmente condicionados pelas crenças que sustentamos (Skinner, 2002a:4). Quando selecionamos determinados eventos do passado e os elevamos à categoria de fatos, estamos, ao mesmo tempo, ignorando uma infinidade de outros eventos, muitas vezes por sequer estarmos capacitados para perceber sua própria existência. Os fatos não falam por si, e nosso acesso à realidade é irremediavelmente theory-laden.

É curioso observar que críticos que acusam Skinner de positivista e objetivista não se furtam de também criticá-lo pelo pecado oposto. É o caso do próprio Keane, quando denuncia o "viés subjetivista da nova história" (Keane, 1988:206). Neste caso, é o intencionalismo de Skinner que entra em consideração. Baseando-se em Ricoeur, Keane propõe uma distinção entre os "momentos objetivos e subjetivos do significa- 
do", para, em seguida, afirmar que Skinner, ao preocupar-se exclusivamente com as intenções dos autores, perderia completamente de vista "a dimensão objetiva dos proferimentos dos autores", cristalizada na "autonomia semântica de seus textos" (ibid.:207).

O "subjetivismo" (ou "idealismo") de Skinner também é apresentado como resultado de sua suposta crença no caráter autorreferenciado do mundo da linguagem. Ian Shapiro, reclamando um maior compromisso com o "realismo" na história das ideias, afirma que o modelo que os convencionalistas utilizam para o estudo da ação linguística "os impede de examinar os fatos reais" (Shapiro, 1982:561). O desinteresse de Skinner pela análise causal e pela explicitação dos motivos por trás dos atos linguísticos seria uma atitude compatível com o seu "chauvinismo linguístico" (ibid.:546). O verdadeiro "realista", por outro lado, não vê nenhuma razão a priori para considerar os mecanismos causais estudados pelos cientistas sociais como ontologicamente diferentes daqueles estudados pelos cientistas naturais (ibid.:567). Shapiro argumenta, ainda, que este desinteresse pela dimensão dos "fatos reais" (extralinguísticos) resulta em uma perspectiva política pronunciadamente conservadora. A falta de uma teoria realista para o exame dos atos linguísticos levaria Skinner a tomar os proferimentos autorais at face value, baseando-se em meras redescrições das intenções publicamente manifestas dos autores. Isso tornaria impossível "conceber a ideologia como qualquer coisa que não as intenções subjetivas dos teóricos da política. A análise da ideologia torna-se a narrativa de tais intenções, e, como tal, ela impede a atenção às reais funções ideológicas da linguagem" (ibid.:563).

Skinner, contudo, afirma que uma das vantagens de sua abordagem consiste justamente em permitir que se escreva a história das ideias "menos concentrada nos clássicos e mais nas ideologias" (Skinner, 1996:11). O fato é que a concepção de ideologia desposada por Skinner tem como critério principal de definição a função desempenhada pelas ideias na legitimação de instituições e práticas políticas (Tully, 1988:13). O enfoque das ideologias como expressão de uma falsa consciência, ou de crenças distorcidas, ou, ainda, como inversão da realidade material, mais ao gosto dos realistas, é deliberadamente negligenciado, e o conceito de ideologia passa a vincular-se a uma problemática muito mais político-sociológica do que epistemológica. $\mathrm{O}$ fato de determinadas ideias serem verdadeiras ou falsas não teria nenhuma relevância para defini-las como expressões de ideologias. O que importa é o modo pelo 
qual as ideias se vinculam às posições práticas em disputa nos conflitos políticos de determinada época. É a partir deste enfoque que Skinner afirma tão enfaticamente que "o conceito de verdade é irrelevante para a explicação das crenças", e que seguir a recomendação oposta, assumindo o imperativo de determinação da verdade ou falsidade das crenças sustentadas pelos agentes do passado, "é fatal para a boa prática histórica" (Skinner, 2002a:2).

Mas essa recusa de considerações sobre a "verdade" na interpretação das crenças dos agentes do passado não passou impune pela crítica. Para Charles Taylor, por exemplo, se tal recusa é coerente com a concepção de que ideias e conceitos são como "armas" manipuladas na forma de argumentos em conflitos ideológicos, ela, por outro lado, está longe de ser adequada para uma história das ideias que vá além desta perspectiva exclusiva e "radical". Segundo Taylor, a "hermenêutica do conflito" que Skinner compartilharia com outros "neoclausewitzianos" (como Foucault, por exemplo) peca ao tentar isolar o "contexto de luta" do "contexto de verdade" (Taylor, 1988:220). Isto porque, ao fim e ao cabo, tal separação seria impossível. Concentrar o trabalho de interpretação exclusivamente no conflito ideológico, lançando mão de um vocabulário constituído predominantemente de metáforas bélicas, como faz Skinner, somente seria aceitável dentro de uma improvável situação-limite. Ou seja,

somente se pudéssemos mostrar que as relações de dominação e as estratégias que as criam e as sustentam invadiram completamente o mundo de nossa autocompreensão cotidiana, poderíamos adotar a estreita, neoclausewitziana, interpretação acima, e fazer de todas as ideias dominantes o resultado de conflitos centrados na guerra e na luta por poder. (Taylor, 1988:226)

Skinner procura defender-se deste tipo de crítica mediante uma reelaboração do conceito de racionalidade envolvido em suas proposições de método. Em sua defesa, afirma que o que lhe parece errôneo é a tendência de conceber as crenças dos historiadores e intérpretes do presente como o padrão pelo qual deveriam ser julgadas as ideias e crenças dos agentes do passado. Este tipo de "paroquialismo" é prejudicial porque impede o historiador de perceber a racionalidade das crenças dos agentes no contexto específico do passado simplesmente porque tais padrões pretéritos de racionalidade já não se encontram em vigência no contexto contemporâneo do intérprete. Para Skinner, uma concepção substancial e objetiva de razão encontra-se na base deste equí- 
voco. Mas, afastar-se desta concepção de razão não implica renunciar a toda e qualquer concepção de racionalidade. Uma racionalidade situacional e procedimental é defendida como imprescindível na elaboração dos preceitos de uma adequada metodologia de interpretação histórica. Seria perfeitamente possível aos intérpretes revelarem a irracionalidade de determinada crença do passado. Contudo, neste caso,

eles não estariam se perguntando se a crença em questão é racional de acordo com seus próprios padrões (menos ainda $o$ padrão) de racionalidade epistêmica. Eles estariam meramente reportando que ela não era uma crença apropriada para aquele agente particular esposar naquela sociedade em particular, naquela época em particular. (Skinner, 2002a:37-38)

Skinner lamenta que, em nossa "era pós-moderna", este tipo de defesa da ideia de racionalidade seja interpretada por muitos de seus críticos como insuficiente para fornecer critérios mínimos de objetividade e validação do conhecimento, o que revelaria sua completa capitulação a uma espécie de "relativismo conceitual"14. O autor assegura, entretanto, que em momento algum teria assumido este tipo de relativismo, que lhe parece "incompatível com a prática da história intelectual" (ibid.:54). Embora se posicione insistentemente contra a ideia de uma racionalidade universal e, mais ainda, contra a noção abertamente positivista de "fatos puros" como critérios de validação do conhecimento histórico (ibid.:1), Skinner admite que "devemos assumir, antecedentemente à investigação histórica, que nossos antepassados compartilhavam pelo menos algumas de nossas crenças sobre a importância da consistência e da coerência" (Skinner, 1988b:257). Não se trata de afirmar um compartilhamento de crenças universais substantivas entre o intérprete e o agente do passado, mas de admitir um mínimo de pressuposições em comum sobre "o próprio processo de formação de crenças" (ibid.:257).

\section{Intencionalismo}

O compromisso de Skinner com o intencionalismo na história intelectual tem sido questionado desde diferentes perspectivas. Uma compreensão adequada das críticas a este fundamento da metodologia skinneriana deve ter em mente a ampla notoriedade alcançada pelo "caso anti-intencionalista" nos anos 1960 e 1970 do século passado. Já na década de 1950, teóricos da chamada "nova crítica literária" nor- 
te-americana passaram a propagar a tese de que "o desígnio ou intenção do autor não é nem disponível nem desejável como o padrão de julgamento do sucesso de uma obra de arte literária" (Wimsatt e Beardsley, 1954:3). Por caminhos bastante distintos, essa tese encontrou desdobramentos nas vertentes pós-estruturalistas e desconstrucionistas que passaram a configurar, a partir do fim dos anos 1960, o que poderia ser caracterizado como um novo "textualismo" na história intelectual (Jay, 1993). A célebre declaração de Derrida de que "não há nada fora do texto" (Derrida, 1967: 227) foi seguida pela não menos conhecida metáfora da "morte do autor", anunciada por Barthes (1968) e endossada por Foucault (1969). O novo textualismo parte de um radical ceticismo em relação à possibilidade de recuperação do significado original dos textos, especialmente quando se busca associar tal significado às intenções dos autores, como o faz Skinner. Nunca saberíamos ao certo o que um autor quis dizer ou fazer ao escrever o que escreveu. Nem mesmo o próprio autor poderia saber com segurança os reais móveis de sua ação, subjugado que é por motivações que muitas vezes lhe escapam à consciência. Como afirma um dos críticos de Skinner, "à luz da psicanálise, nós não podemos pressupor que um autor tenha tal privilegiado acesso às suas intenções" (Seidman, 1983:83).

Outro tipo de objeção ao intencionalismo skinneriano não contesta a possibilidade de definição do significado de um ato de fala mediante a reconstituição da intenção de quem o efetuou. Todavia, tal critério ainda que legítimo para a compreensão da comunicação oral face a face - é considerado impróprio para o estudo dos significados de textos escritos. Inspirados em argumentos de Paul Ricouer, críticos como Boucher (1985:228-229; 1986), Seidman (1983:84), Harlan (1989) e Feres Jr. (2005) chamam a atenção para as especificidades do fenômeno da inscrição do discurso, indicando os obstáculos para a apreensão desse fenômeno pela teoria dos atos de fala. Com efeito, para Ricouer:

Com o discurso escrito, a intenção do autor e o significado do texto cessam de coincidir. Esta dissociação entre o significado verbal do texto e a intenção mental é o que está realmente em questão na inscrição do discurso. Não que possamos conceber um texto sem um autor; a ligação entre o autor e o discurso não é abolida, mas distendida e complicada. [...] a carreira do texto escapa ao finito horizonte vivido por seu autor. (Ricoeur, 1979:78)

No texto escrito, desaparecem parcialmente os elementos de prosódia que, na conversação oral, facilitam a identificação do significado da 
sentença com a intenção do falante. Além disso, conforme Ricouer (ibid.), a inscrição do discurso "explode" a estreiteza da situação que caracteriza a comunicação oral, na medida em que estabelece uma espécie de autonomização do discurso de seus referentes imediatos. Nas condições particulares de uma situação dialógica, o caráter referencial do discurso aparece de maneira "ostensiva". Somente o discurso escrito, "ao libertar-se, não somente de seu autor, mas dos constrangimentos de uma situação dialógica", poderia viabilizar uma espécie de "abertura", capaz de revelar-nos "novas dimensões de nosso ser no mundo" (Ricouer, 1979:79). Mas a mais importante distinção entre o discurso escrito e o discurso presente na conversação ordinária consistiria no fato de que, no primeiro caso, as sentenças deixam de ser endereçadas a um "interlocutor igualmente presente na situação do discurso". O discurso escrito é destinado a uma audiência que "se cria a si própria". Qualquer um que possa ler é potencial destinatário da locução contida no texto, o que revela a "espiritualidade" e a "universalidade" do discurso. Ao escapar das limitações de uma conversação face a face, o discurso deixa de ter um "autor visível", ao mesmo tempo em que um "um desconhecido e invisível leitor passa a ser o destinatário não privilegiado do discurso" (ibid.:80).

Retomando a taxonomia dos atos de fala de Austin, Ricouer afirma que a única dimensão do significado que permanece idêntica quando se transita da situação de diálogo direto para o discurso escrito é a dimensão locucionária do proferimento linguístico. O conteúdo proposicional de um enunciado não se altera, pois depende exclusivamente da presença de determinadas palavras - expostas numa determinada ordem - numa sentença. "A sentença pode, com efeito, ser identificada e reidentificada como sendo a mesma sentença" (ibid.: 76). O mesmo não ocorre com o ato ilocucionário, que só de modo parcial pode ser representado no discurso escrito. Ainda que se considerem os "paradigmas gramaticais" que auxiliam na indicação da força ilocucionária de determinada sentença, tais como os modos verbais (indicativo, imperativo e subjuntivo), o discurso escrito não pode incorporar os "elementos gestuais" e os "aspectos não articulados do discurso" presentes na situação de fala. Já a dimensão perlocucionária do ato de fala perde-se completamente no discurso escrito. E aí residiria o maior obstáculo aos que desejam mobilizar o modelo da conversação ordinária para a compreensão de textos escritos. Os efeitos nas emoções e nas predisposições afetivas dos agentes (falantes e ouvintes) de um ato 
comunicativo, tão ostensivos na conversação ordinária, não encontram meios de expressão e fixação no discurso escrito.

Essas considerações de Ricoeur permitem aos críticos do intencionalismo skinneriano argumentarem também que a speech acts theory não fornece subsídios para que se considere o princípio da "independência relativa do texto" (Feres Jr., 2005:673), obscurecendo o papel dos leitores e minando as possibilidades de uma história da recepção. Ao reduzir o texto a um ato de fala compreensível apenas mediante a recuperação das intenções autorais em um contexto sincrônico de convenções linguísticas, Skinner estaria perdendo de vista a dimensão diacrônica da vida do texto, manifesta na história dos efeitos produzidos nos leitores pelo conteúdo proprosicional (ato locucionário) dos enunciados contidos no texto.

O intencionalismo skinneriano é também acusado de promover uma equivocada identificação entre ato ilocucionário e intenção ilocucionária. Graham, por exemplo, afirma que seria perfeitamente possível a ocorrência de um ato ilocucionário não intencional, bem como a existência de uma intenção ilocucionária que não se efetiva em ação. Exemplo deste segundo caso seria minha tentativa de provocar interesse em uma determinada audiência em uma situação em que tal audiência fosse "surda, ou estúpida, ou estrangeiros não familiarizados com a língua" (Graham, 1988:151-152). Já o conceito de "ato ilocucionário não intencional", não admitido na metodologia de Skinner, aponta para a possibilidade, contemplada apenas de passagem por Austin (1975:106), de determinados proferimentos carregarem consigo uma força ilocucionária completamente independente das intenções de seus autores. Conforme esclarece Boucher, isto poderia ocorrer em situações em que o contexto do proferimento é governado por convenções linguísticas fortes (Boucher, 1985:221). O que um agente faz, de fato, ao proferir sentenças em tais condições, depende menos de sua intenção ao dizer o que disse do que das convenções linguísticas que regulam a recepção do conteúdo semântico do ato linguístico. O sujeito da ação linguística pode, por exemplo, ofender pessoas, sem ter essa intenção, simplesmente por não estar bem informado a respeito das convenções prevalecentes em dada situação ${ }^{15}$.

A ênfase que Skinner atribui à intenção ilocucionária dos autores-escritores para a compreensão do significado histórico da ação linguística tem sido alvo de objeções provenientes do próprio campo intencio- 
nalista, como se observa na série de artigos de Mark Bevir invectivando contra o contextualismo linguístico (Bevir, 1992; 1994; 1997; 2000). Em seu amplo projeto de reforma da perspectiva intencionalista na história das ideias, Bevir reconhece que Skinner, mediante sua distinção entre "motivos" e "intenções", procura distanciar-se das abordagens mais ortodoxas do intencionalismo, que tendem a identificar a noção de intenção autoral com os propósitos originais e conscientes dos autores, propósitos antecedentes ao - e contingentemente conectados com o - enunciado. Porém, ainda que Skinner não possa ser acusado deste erro do "intencionalismo forte", sua abordagem peca ao tentar captar o significado histórico de uma obra recorrendo exclusivamente à força ilocucionária dos enunciados, o que o leva a enfatizar, no processo de compreensão, os "desejos" e "pró-atitudes" de um dado autor, em vez das "crenças" que ele sustenta. Para Bevir, não se trata de "excluir todos os desejos do aspecto intencional da ação", mas de defender o ponto de vista de que tais desejos "não entram no significado de uma obra" (Bevir, 1999:69). A perspectiva intencionalista deveria ater-se muito mais ao universo de "crenças substantivas" dos autores do que aos desejos e pró-atitudes manifestos em seus atos ilocucionários. Além disso, Bevir acusa Skinner de compartilhar com o "intencionalismo forte" o equívoco de ignorar o papel dos leitores na atribuição de significado a um determinado texto, fazendo da intenção do autor original (o criador do texto) o critério exclusivo da interpretação. Mas por que ignorar o papel ativo de leitores na atribuição dos significados? Segundo Bevir, Skinner parece assumir que, de certo modo, os textos têm significados em si mesmos, não importando o que seus intérpretes e leitores pensem a seu respeito. E, do ponto de vista histórico, o significado que o texto carrega consigo teria sido determinado pela intenção de seu autor no contexto original de sua produção. Este significado histórico, de uma vez por todas estabelecido no passado, estaria à espera para ser "corretamente" recuperado pela mobilização do instrumental metodológico apropriado à empreitada. Bevir, por seu turno, além de duvidar da crença de que um método, qualquer que seja, possa ter a virtude de garantir uma interpretação correta, também argumenta que textos não têm significados em si mesmos. Sem a intervenção humana, textos nada mais são do que marcas registradas em papel ou outro meio físico. São os indivíduos (tanto autores quanto leitores), dotados de capacidade de agência, que a eles atribuem significados.

Os esforços de Skinner no sentido de defender seu compromisso com o intencionalismo têm se refletido tanto em refinamento e desenvolvi- 
mento de suas ideias originais, quanto em crescente número de ambiguidades e contradições que se vão acumulando em sua obra. A estratégia geral da defensiva skinneriana consiste na insistência do autor em marcar sua diferença em relação às variantes intencionalistas mais ortodoxas na teoria da interpretação. Para Skinner, a tese de que o "significado verbal" de um texto "requer a determinação da vontade do autor", tese difundida por autores como Hirsch $(1967 ; 1976)$ e Juhl (1980), seria o verdadeiro alvo daqueles anti-intencionalistas que o têm criticado por supostamente propagar a "falácia intencionalista". Skinner assegura que nunca teria se engajado em tal linha de argumentação, e que nas ocasiões em que a ela se referiu teria sido para endossar o caso anti-intencionalista ${ }^{16}$. Chega mesmo a afirmar que não acredita que "as intenções dos falantes ou escritores constituam o único, ou mesmo o melhor guia para a compreensão de seus textos ou enunciados" (Skinner, 2002a:110); e, ainda, que está longe de supor "que os significados dos textos possam ser identificados com as intenções de seus autores" (ibid.:114).

Difícil não perceber, à luz dos primeiros ensaios metodológicos do autor, o evidente recuo presente nas formulações acima. É verdade que elas encontram certo respaldo em alguns de seus textos anteriores, já destinados a contra-atacar os anti-intencionalistas. Lembremo-nos de sua distinção entre os diferentes tipos de significados (meaning 1, meaning 2, e meaning 3) passíveis de serem atribuídos a determinado enunciado (Skinner, 1972). Contudo, se anteriormente Skinner falava de uma "equivalência" entre o significado histórico (meaning 3) de um enunciado e a intenção ilocucionária do autor, prefere agora ficar apenas com o ponto de que sua "preocupação principal tem sido não com significado, mas, antes, com a performance de atos ilocucionários" (Skinner, 2002a:111).

Como que para não ficar completamente destituído de seu ponto original, Skinner destaca que, ao menos em certos casos, a interpretação histórica de um texto não pode prescindir do conhecimento das intenções de seu autor. Se este princípio não pode ser desconsiderado de todo no estudo de textos "sérios", ele é imprescindível e central quando nos reportamos a textos mais problemáticos, como aqueles em que nos defrontamos "com códigos retóricos escondidos tais como os da ironia" (id.). No texto irônico há um flagrante afastamento entre o conteúdo semântico (ou locucionário) e o significado do texto para o autor. Assim, o analista que permanecesse concentrado exclusivamente no 
nível semântico das locuções contidas no texto correria o risco de produzir uma interpretação historicamente absurda. Revelar-se-ia aí, de forma mais evidente, a indispensabilidade do conhecimento sobre o que o autor "estava fazendo" quando da escritura ou publicação do texto para a compreensão do "ponto" de seu proferimento enquanto ação linguística ${ }^{17}$.

Mas o que fica claro é que, ao defender seu intencionalismo, Skinner arrefece consideravelmente sua pretensão de identificar o significado histórico de um enunciado à intenção ilocucionária do autor. Isso, contudo, não o remete ao encontro das conclusões dos céticos radicais, resumidas na decretação da "morte do autor". Skinner lastima o que considera a redução da teoria da interpretação a um "estudo 'consumidor-orientado' das respostas dos leitores" (Skinner, 1988b:272). Considera que a principal deficiência de tal redução consiste na ausência de elementos de compreensão dos processos de mudanças conceituais. Ou seja, "se desejamos fazer justiça àqueles momentos em que uma convenção é desafiada ou um lugar comum é efetivamente subvertido, nós não podemos simplesmente dispensar a categoria de autor" (ibid.:276). Quanto às convenções linguísticas, elas deveriam ser compreendidas não apenas como constrangimentos à ação dos agentes, mas também como recursos que tais agentes mobilizam para a efetuação da ação ${ }^{18}$.

\section{Antiquarismo}

As críticas ao "antiquarismo" skinneriano começaram a aparecer já nos primeiros lances do debate metodológico em questão (Leslie, 1970; Parekh e Berki, 1973; Tarlton, 1973). Tratava-se da contrapartida aos ataques do próprio Skinner ao "anacronismo" presente nas modalidades convencionais na história das ideias. Como vimos, Skinner considerava um erro metodológico o estudo dos textos dos autores clássicos como expressões de verdades supostamente intemporais e universais. Neste ponto, o autor continua a argumentar que a possibilidade de aprendermos algo de novo com os autores do passado dependeria de nosso esforço para "ver as coisas do modo deles" (Skinner, 2002a:3). E isso só seria possível por meio do cuidadoso trabalho de reconstituição do contexto linguístico e normativo em que os autores, clássicos ou não, estavam imersos. A tentação de uma historiografia "presentista", motivada pelo desejo de se retirar diretamente dos textos dos autores clássicos as soluções dos problemas atuais, além de um equívoco teóri- 
co, consistiria também num erro moral, uma vez que o presentismo representaria uma espécie de evasão da tarefa intransferível de encontrarmos, mediante nosso próprio esforço, as possíveis soluções para nossos dilemas políticos e morais. Daí a máxima, desde cedo advogada por Skinner, segundo a qual "devemos aprender a pensar por nós mesmos" (1969:52).

Os oponentes de Skinner suspeitavam que, levadas à prática tais prescrições, o estudo do passado perderia sentido. Tudo o que teríamos ao final de uma exaustiva investigação seria algo como uma relíquia exótica em nosso mundo presente. Quem se motivaria a aventurar-se numa tal empreitada? Em vez de despertar o interesse pela história das ideias, tal atitude resultaria num aprofundamento do desinteresse pelo passado, na medida em que desconsideraria o fato, posto em relevo na hermenêutica filosófica de Gadamer, de que

Nas ciências do espírito o interesse do investigador que se volta para a tradição é motivado, de uma maneira muito especial, pelo respectivo presente e seus interesses. É só pela motivação do questionamento que se estabelece o tema e o objeto da investigação. Com isso, a investigação histórica se sustenta no movimento histórico em que se encontra a própria vida, e não se deixa entender teleologicamente a partir do objeto a que se orienta a investigação. (Gadamer, 2004:377-378)

Para os críticos de Skinner vinculados à perspectiva gadameriana, a investigação histórica deve ter como objeto não "autores mortos, mas livros vivos", e seu objetivo é compreender o modo como determinadas obras podem "sobreviver ao seu passado" para "falar-nos sobre nosso presente" (Harlan, 1989:609). Em vez da individualização do passado e de sua fixação em um contexto radicalmente distinto do contexto do próprio intérprete, dever-se-ia enfatizar as continuidades entre passado e presente; de outro modo, a própria noção de tradição intelectual seria inconcebível (Lockyer, 1979). Caberia ao historiador a busca do significado de um texto por meio de um "diálogo" com as obras clássicas, buscando a "fusão de horizontes" entre passado e presente. Mas a metodologia skinneriana não viabilizaria - e até mesmo interditaria esse diálogo, lançando sobre os ombros do historiador as pesadas exigências da "história documental" (LaCapra, 1982), esteio de uma narrativa destinada a apresentar o passado como uma série de eventos singulares e desconexos no curso do tempo. Porém, "se todos os eventos são sui generis, não podemos escrever história; podemos apenas empilhar documentos" (Femia, 1988:127). Aponta-se como uma ironia 
o fato de que Skinner, tão cioso na denúncia de "mitologias", teria sucumbido, ele próprio, numa "mitologia da fragmentação" (Minogue, 1988:179), na qual a própria ideia de processo histórico perderia completamente seu sentido.

Argumenta-se também que o interesse exclusivo pelo contexto imediato de produção do texto resultaria na diluição de grandes ideias de grandes autores numa miríade de textos de pouca significação, instaurando a tendência "de depreciar o texto em favor do contexto" (Gunnell, 1982:322). Ao interpretar o significado dos textos clássicos à luz da atividade de "panfletários" que escrevem para uma audiência muito restrita, Skinner estaria promovendo uma confusão entre os diferentes níveis de abstração em que as ideias políticas aparecem na história, passando ao largo do fato de que "o nível de abstração de um texto está em relação inversa com sua relevância para uma específica audiência e contexto histórico" (Parekh e Berki, 1973:174). Skinner pecaria por não reconhecer que os textos que consideramos clássicos na história do pensamento político foram, em geral, elaborados em elevado nível de abstração e tratam de problemas que são, de certo modo, "perenes".

Como Skinner tem reagido a essa ordem de objeções? Não há dúvida de que tais acusações o perturbam intensamente. O autor escreveu, recentemente, ter "previsto essa objeção depressivamente filistina", mas lamenta que suas primeiras tentativas de resposta "estiveram longe do suficiente para satisfazer seus críticos", haja vista a reincidência da acusação de antiquarismo (Skinner, 2002a:6). O fato é que em sua defesa, Skinner é forçado a trilhar uma linha de reflexão que, para dizer o mínimo, não estava contida em suas declarações metodológicas iniciais. Afirma que o ceticismo em relação à possibilidade do aprendizado de uma sabedoria universal e intemporal dos textos do passado não significa que nada de contemporaneamente relevante se possa aprender com o estudo da história. Uma das principais vantagens do estudo da história do pensamento para o entendimento do presente residiria no incremento de nossa percepção da natureza contingente de nossas próprias crenças atuais. As ideias que circulam no presente estão longe de representar o coroamento de um processo racional de desenvolvimento ideológico, para o qual os pensadores clássicos teriam contribuído decisivamente. O que pensamos e como pensamos são produtos de conflitos ideológicos cujos resultados poderiam (e podem) ser diferentes do que são. Isso também vale para o passado, que é pleno de possi- 
bilidades não efetivadas, de ideias derrotadas, de projetos e de valores esquecidos. Ao aprendermos que os conceitos que herdamos do passado são resultados contingentes de escolhas e conflitos, em que também têm lugar a força, a habilidade retórica dos contendores, e mesmo certa dose de acaso, estaremos mais bem equipados para o necessário e sempre difícil procedimento de "desnaturalização" de nossas crenças. O estudo da história do pensamento político capacita nosso esforço para escaparmos do "paroquialismo" de nossos próprios valores (ibid.:88-89).

Além disso, prossegue Skinner, o estudo das ideias do passado pode ajudar no desenvolvimento de um "certo tipo de objetividade", resultante da contemplação de "sistemas rivais de pensamento". Do mesmo modo, podemos atingir um "grau maior de compreensão" e, portanto, maior "tolerância" em relação a elementos de "diversidade cultural" (ibid.:125). Por fim, o estudo da história do pensamento político é relevante para o pensamento político do presente na medida em que serve para enriquecermos nossa percepção sobre conceitos herdados do passado e usados de maneira "empobrecida" na atualidade. Ou seja, "ao retornarmos para olhar como esses conceitos eram mobilizados em tradições de pensamento passadas, podemos encontrar uma discussão mais rica dos conceitos que continuamos a empregar" (Skinner, 1997:74) ${ }^{19}$. Em suma, para Skinner,

A história da filosofia, e talvez especialmente da filosofia moral, social e política está aí para nos impedir de sermos muito facilmente enfeitiçados. O historiador do pensamento político pode nos ajudar a apreciar até onde os valores incorporados em nosso modo atual de vida, e nossas atuais maneiras de pensar sobre esses valores, refletem uma série de escolhas feitas em épocas diferentes entre diferentes mundos possíveis. Essa consciência pode ajudar a libertar-nos do domínio de qualquer uma das explicações hegemônicas desses valores e de como eles devem ser interpretados e compreendidos. Munidos de uma possibilidade mais ampla, podemos nos distanciar dos compromissos intelectuais herdados e exigir um novo princípio de investigação sobre esses valores. (Skinner, 1999a:93-94)

Este tipo de justificativa para a prática da história intelectual em benefício da crítica e da (re)formulação da teoria política contemporânea tem encontrado ressonância em inúmeros autores simpáticos à abordagem skinneriana (Janssen, 1985; Ball, 1995; Runciman, 2001; Edling e Morkenstam, 1995; Palonen, 2002; 2003). O trabalho do historiador 
intelectual é apontado como uma espécie de preparação de terreno para o trabalho do teórico contemporâneo, uma condição para que este possa pensar além das amarras do passado e do paroquialismo do presente. Não se trata de recuperar um tipo de conhecimento substantivo de um passado ainda vivo no presente. Skinner procura afastar-se desse essencialismo sugerindo que o que está em jogo é, antes, a ampliação de uma capacidade cognitiva, a um só tempo crítica e analítica. Conforme observou Marcelo Jasmin, para Skinner, as pesadas exigências em termos de documentação do passado funcionam "na outra ponta, a da teoria contemporânea, como uma espécie de carta de alforria para a imaginação que deve deixar ao passado os seus termos e partir para uma inovação conceitual adequada aos problemas 'locais' do tempo presente" (Jasmin, 2005:30).

Resta saber se, além de distante, a visão skinneriana mais recente sobre a relação entre passado e presente não seria também contraditória com suas prescrições metodológicas das décadas de 1960 e 1970. O mínimo que se pode dizer é que Skinner encontraria grande dificuldade para justificar o esforço empreendido em seus estudos sobre, por exemplo, a história dos conceitos de Estado e liberdade por meio de suas formulações metodológicas clássicas. Vale lembrar que já em 1979, na conclusão de seu livro mais famoso, Skinner assinalava que sua preocupação teria sido estudar o "processo" de "formação" do conceito moderno de Estado, um processo que se completara no começo do século XVII, mas cujos "pré-requisitos" vinham se estabelecendo desde meados do século XIII (Skinner, 1996:617). Sua narrativa da história do conceito de liberdade é ainda mais abrangente. Trata desde os moralistas romanos da Antiguidade, até aos republicanos ingleses do século XVII, detendo-se, com detalhe, nos pensadores do Renascimento italiano, especialmente em Maquiavel. Além disso, em seus textos sobre a história do conceito de liberdade, Skinner não se furta de arrolar inúmeras referências a teóricos contemporâneos, de Isaiah Berlin a Charles Taylor, de Gerald McCallun a Philip Pettit.

Recentemente, quando questionado se não receava que o "Skinner filósofo" estivesse, pouco a pouco, eclipsando o Skinner historiador, especialmente em seus estudos sobre a teoria da liberdade, o autor concedeu que a pergunta lhe servia como um bem-vindo alerta, embora a questão o colocasse diante de um "dilema" que é próprio de todo e qualquer estudioso das humanidades: "De um lado, queremos que nossos estudos sejam tão eruditos quanto possível. Do contrário, eles 
serão pouco melhores do que obras de propaganda. Mas, por outro lado, certamente queremos que nossos estudos sejam de algum valor para nossas sociedades" (Skinner, 2007:118). A solução encaminhada para tal dilema é mais uma evidência da distância que hoje separa Skinner de sua antiga ênfase antipresentista. Em termos que lembram muito uma clássica formulação de Weber, em polêmica com Eduard Meyer $^{20}$, Skinner sai em busca da reconciliação entre presentismo e historicismo.

Nossa escolha do que estudar deve ser motivada por nosso sentimento do que é importante aqui e agora. Devemos selecionar os objetos que estudamos à luz de eles terem algum tipo de significação social geral. Mas, uma vez selecionados tais objetos, devemos ser tão rigorosos quanto possível em nossas pesquisas, porque, de outro modo, nossos achados carecerão de integridade e autoridade. (Skinner, 2007:119)

Diferentemente da "fusão de horizontes" de Gadamer, a "aproximação" de horizontes skinneriana continua reservando um lugar de destaque ao método. É um equívoco censurar Skinner por dar importância à metodologia em sua teoria da interpretação histórica. Não obstante, é preciso denunciar o equívoco do próprio do autor ao sugerir que suas prescrições oferecem o caminho inevitável (necessário e suficiente) a quem queira estudar o pensamento político a partir de um enfoque "genuinamente" histórico (Skinner, 1972:406; 1988b:275). Não há dúvidas de que o contextualismo linguístico tem contribuído decisivamente para robustecer o campo da história do pensamento político, mas o mesmo poderia ser dito de outras abordagens. A história intelectual consiste em uma prática disciplinar particularmente arredia ao império de ortodoxias. A história da teoria política, em particular, é uma atividade do tipo "problem-solving" (Ball, 1995:29), e a diversidade de problemas sobre os quais se debruçam os historiadores intelectuais ajuda a explicar a pluralidade de métodos e técnicas heurísticas. Pode-se concluir que tal ou qual método é mais apropriado do que os demais para tratar de determinado problema, mas não que haja um método absolutamente superior aos outros para o equacionamento e resolução de todo e qualquer problema. A "objetividade" de determinada interpretação não pode ser assegurada pelo método empregado. É perfeitamente possível que o intérprete, mesmo mobilizando uma metodologia sofisticada, chegue a uma interpretação pobre de determinado fenômeno. Inversamente, nada impede que mesmo partindo de uma metodologia pouco elaborada ele alcance resultados satisfató- 
rios. A narrativa final é que deve submeter-se aos critérios de objetividade, não o método que a inspirou.

Duvidar da existência de um método infalível não significa naufragar no oceano do relativismo radical. É verdade que não temos mais o tribunal dos "fatos puros" para julgarmos pretensões de objetividade, e também não podemos recorrer ao "juizado dos procedimentos metodológicos". Podemos, entretanto, continuar comparando, à luz da melhor evidência disponível, os resultados finais das pesquisas históricas e apontar aquelas narrativas que, em comparação com narrativas rivais, nos oferecem interpretações mais acuradas, compreensivas, consistentes, profícuas, progressivas e abertas das ideias do passado.

(Recebido para publicação em fevereiro de 2009)

(Versão definitiva em setembro de 2009)

\section{NOTAS}

1. Com algumas exceções, os críticos têm passado ao largo de importantes diferenças de ênfase entre a abordagem de Skinner e a de Pocock, quando até mesmo os autores as reconhecem. Enquanto Skinner enfatiza a necessidade de recuperação das "intenções autorais" no processo de compreensão do significado da "ação linguística" , Pocock está mais preocupado com a reconstituição de "paradigmas", "linguagens" e "discursos" políticos que informam o significado de um texto. Para Pocock, as intenções dos autores têm caráter derivado, uma vez que as linguagens funcionam "paradigmaticamente, prescrevendo o que ele [o autor] deve dizer e como dizê-lo" (1972: 25). Assim, "os modos de discurso disponíveis dão-lhe as intenções que ele pode ter, ao proporcionar-lhe os únicos meios de que ele poderá dispor para efetuá-las" (Pocock, 2003:27-28, ênfases minhas). É declarada a insatisfação de Skinner com a ênfase pocockiana na função paradigmática das linguagens: "Se a ênfase de Greenleaf nas tradições ou a de Pocock nas linguagens forem tratadas como metodologias em si mesmas, elas estão prestes a gerar pelo menos duas dificuldades. Existe um perigo óbvio de que, se enfocarmos meramente a relação entre o vocabulário usado por um dado escritor e as tradições com as quais ele pode parecer conectado por seu uso desse vocabulário, podemos nos tornar insensíveis para as instâncias da ironia, obliquidade, e outros casos em que o escritor pode parecer estar dizendo algo diferente do que quer dizer. O principal perigo, porém, é que, se nos concentrarmos meramente na linguagem de um dado escritor, corremos o risco de assimilá-lo a uma tradição intelectual completamente estranha, e, logo, de não compreendermos o objetivo geral de sua obra política" (Skinner, 1974:288). 


\section{Ricardo Silva}

2. A obra substantiva de Skinner, ao contrário de seus textos metodológicos, tem encontrado grande difusão no contexto brasileiro (Skinner, 1988c; 1996; 1999a; 1999b). Recentemente, editou-se em Portugal a tradução do primeiro volume da trilogia publicada pelo autor com vistas a revisar e reunir seus principais ensaios. O primeiro volume concentra-se, exclusivamente, em questões de método (Skinner, 2005).

3. Examinando retrospectivamente o surgimento da Escola de Cambridge, Pocock refere-se a Laslett como o "protagonista", um "homem extraordinário" que "deslanchou uma revolução local cujos efeitos foram sentidos por muitos anos" (Pocock, 2004: 535). Afirma, também, que seu próprio livro de estreia, The Ancient Constitution and the Feudal Law, de 1957, foi escrito já sob a influência do trabalho que vinha sendo desenvolvido por Laslett desde o fim da década de 1940. Skinner, que teve Laslett como seu tutor em Cambridge, é ainda mais enfático ao atestar o pioneirismo de Laslett, relembrando que achou "maravilhosa, em vários sentidos", sua introdução à reedição dos Dois Tratados sobre o Governo, tanto pela elegância do texto, quanto pelas descobertas sobre Locke que lhe pareciam "metodologicamente interessantes" (Skinner, 2002b:214). Ver também Skinner (1997:69).

4. Trata-se da mais conhecida e citada referência ao método do contextualismo linguístico. Skinner afirma que o tom hiperbolicamente crítico do ensaio, escrito como uma espécie de "manifesto", fazia parte de uma estratégia para "chocar" e "irritar" (Skinner, 2002b:218). Embora o ensaio tenha sido rejeitado, na época, por vários periódicos, até ser aceito para a publicação no oitavo volume da revista History and Theory, o autor avalia que sua estratégia foi bem-sucedida, a julgar pela atenção que passou a receber dos críticos.

5. A lista de autores atacados por Skinner sob tal rubrica era extensa, destacando-se nomes como os de Leo Strauss, George Sabine e John Plamenatz. A denúncia dos erros textualistas visava também o influente pensador norte-americano Arthur Lovejoy, fundador, em 1940, do Journal of History of Ideas e autor, dentre outros, do clássico The Great Chain of Being, de 1936. Parte do debate em torno das posições de método de Lovejoy foi reunida em Kelley (1990).

6. Skinner refere-se a Lewis Namier, influente historiador no contexto acadêmico britânico de meados do século XX e autor de extensa obra no campo da história intelectual. Para Skinner, Namier tinha em comum com seus próprios adversários marxistas o fato de estar "compromissado com duas alegações sobre as relações entre princípios e prática na vida pública. A primeira é que estamos realmente justificados em desconsiderar os ideais professados por políticos, já que tantos deles tentam revestir suas condutas com o que Namier gosta de descrever como um espúrio ar de moralidade e racionalidade. A segunda alegação, que se segue da primeira, é que tais princípios não desempenham nenhum papel causal em suas ações, e, assim, não precisam figurar em nossa explicação de seus comportamentos" (2002a:145).

7. Mais extensamente em Skinner (2001).

8. "Por exterior do acontecimento, entendo tudo o que lhe pertence, mas que pode ser descrito em termos de corpos e de seus movimentos: a passagem de César, acompanhado por certos homens, dum rio chamado Rubicão, em certa data, ou o derramamento do seu sangue sobre o soalho do Senado, noutra data. Por interior do acontecimento, entendo aquilo que nele só pode ser descrito em termos de pensamento: o desprezo de César pelas leis da República ou a divergência de política constitucional entre ele e os seus assassinos" (Collingwood, s./d.:266). 
9. Em recente tentativa de afastar-se de uma interpretação mentalista e subjetivista da noção de intenção autoral, muitas vezes atribuída a Collingwood e a ele próprio, Skinner afirma que "nada do que estou dizendo pressupõe a desacreditada ambição hermenêutica de colocar-se enfaticamente no lugar dos outros e tentar (na infeliz frase de Collingwood) repensar seus pensamentos depois deles. A razão pela qual nenhum truque deste tipo é necessário é que, como Wittgenstein afirmou há muito tempo ao criticar o conceito de uma língua privada, as intenções com as quais alguém efetua um ato bem-sucedido de comunicação devem, ex hypothesi, ser publicamente apreensíveis" (Skinner, 2002a:120).

10. Também em Skinner (1988a:88; 1971:15). Nadia Urbinati, em recente avaliação da contribuição de Skinner, afirma que a "distinção entre motivos e intenções é talvez uma das mais importantes realizações teóricas da aplicação da análise linguística ao estudo histórico" (Urbinati, 2005:91).

11. Uma intenção "publicamente apreensível" não implica que o ato ilocucionário deva sempre se apresentar explícita e declaradamente, recorrendo-se, por exemplo, ao uso de verbos performativos nas sentenças. Afirmar tal necessidade teria sido, segundo Skinner, o erro de Strawson (1964) em sua tentativa de superar certas lacunas na teoria de Austin. Skinner argumenta que há determinados tipos de atos ilocucionários (oblíquos, não-sincrônicos etc.) que não somente não requerem a declaração da intenção, como seriam mesmo prejudicados se tal declaração fosse explicitada na conversação. Este é o caso típico de atos ilocucionários efetuados com a intenção de ironizar ou ridicularizar uma determinada convenção ou curso de ação (Skinner, 1970).

12. Entre os críticos que argumentam que Skinner não teria propriamente uma metodologia para a história intelectual destaca-se John Gunnell. Para Gunnell, Skinner apresenta argumentos epistemológicos da teoria da interpretação como se isso fosse o suficiente para qualificar uma metodologia (Gunnell, 1982:76). Por outro lado, um autor como Kenneth Minogue (1988), dá a entender que o problema skinneriano era exatamente o oposto: o de constranger a análise histórica com uma excessiva parafernália metodológica. Para Minogue, todo historiador já teria uma ideia, ainda que algo intuitiva, sobre como proceder em sua prática disciplinar. A excessiva preocupação metodológica poderia levar ao autoaprisionamento em uma "camisa de força". Minogue aconselha Skinner a livrar-se do "excesso de bagagem" (Minogue, 1988:193) para que a análise histórica siga seu melhor curso.

13. Para uma história do papel do Instituto de Estudos Avançados de Princeton na crítica ao positivismo e na difusão de diferentes estilos de "ciência social interpretativa", ver a coletânea de ensaios reunidos em Scott e Keates (2001).

14. A exemplo de Hollis (1988:146), Shapiro (1982:537) e King (1983:297).

15. A metodologia intencionalista de Skinner padeceria também da incapacidade para o reconhecimento e a análise de intenções que permanecem imperceptíveis na consciência do autor de um ato linguístico (Rogers, 1990:270). Além disso, não forneceria meios para a investigação do papel de uma classe de intenções que, embora constitutivas do estado mental do autor de um texto, não encontram meios de tornarem-se publicamente manifestas no proferimento linguístico. A importância dessa classe de "intenções irrecuperáveis" revelar-se-ia, sobretudo, no estudo de textos de grande complexidade e valor estético, as quais qualificamos como "obras" literárias (Rosebury, 1997:22). 


\section{Ricardo Silva}

16. Em ensaio recente sobre o intencionalismo, Vivienne Brown (2007:49) alerta para convergências não contempladas por Skinner entre sua própria abordagem e as abordagens de intencionalistas radicais como Hirsch e Juhl.

17. O exemplo constantemente mobilizado por Skinner para ilustrar essa tese é o panfleto de Daniel Defoe, The Shortest-Way with the Dissenters, em que Defoe, ironicamente, de modo a ridicularizar e abalar a legitimidade das crenças de intolerância religiosa de sua época, propõe a execução sumária de "infiéis" dissidentes.

18. Ao destacar a capacidade seletiva (criativa?) dos autores diante das convenções estabelecidas, Skinner procura defender-se da acusação de "determinismo linguístico", que alguns críticos consideram inerente a sua abordagem contextualista (por exemplo: Tarlton, 1973; King, 1995; Bevir, 2000; Diggins, 1984; Turner, 1983).

19. Exemplo disto seria o conceito de liberdade. O autor identifica um empobrecimento no tratamento contemporâneo desse conceito central da teoria política ocidental, uma vez que as discussões atuais reproduzem a dicotomia entre liberdade positiva e liberdade negativa, tributária do pensamento liberal do século XIX. Skinner argumenta que o conceito de liberdade recebera um tratamento mais elaborado no começo da era moderna. Inúmeros pensadores associados à tradição republicana teriam operado com uma ideia de liberdade que incorpora elementos tanto da concepção positiva, quanto da negativa. O conceito de liberdade tem sido tema de inúmeras contribuições de Skinner. Por exemplo: Skinner (1999a; 1984; 1983, dentre outros). Ver, a propósito, Silva (2008).

20. "'Subjetiva', num determinado sentido, que não voltaremos a explicar, não é a constatação das 'causas' históricas de um 'objeto' de explicação dado, mas a delimitação de 'objeto' histórico mesmo, de 'indivíduo' mesmo, pois aqui decidem relações de valor cuja 'concepção' está submetida à mudança histórica” (Weber, 1992:189).

\section{REFERÊNCIAS BIBLIOGRÁFICAS}

AUSTIN, John Langdon. (1975), How To Do Things with Words (2a ed.). Cambridge, Massachusetts, Harvard University Press.

BALL, Terence. (1995), Reappraising Political Theory. Oxford, Clarendon Press.

BARTHES, Roland. (1968), “La Mort de L'auteur". Mantéia, vol. 5, no 4, pp. 12-17.

BEVIR, Mark. (1992), "The Errors of Linguistic Contextualism". History and Theory, vol. 31, pp. 267-298.

. (1994), "Are There Perennial Problems in Political Theory?". Political Studies, vol. XLII, pp. 662-675.

. (1997), "Mind and Method in the History of Ideas". History and Theory, vol. 36, pp. 167-169.

(1999), The Logic of the History of Ideas. Cambridge, Cambridge University Press. 


\section{O Contextualismo Linguístico na História do Pensamento Político...}

(2000), "The Role of Contexts in Understanding and Explanation". Human Studies, vol. 23, pp. 395-411.

BOUCHER, David. (1985), Texts in Context: Revisionist Methods for Studying the History of Ideas. Dordrecht, Martius Nijhoff.

(1986), "Conversation and Political Thought". New Literary History, vol. 18, no 1, pp. $59-75$.

BROWN, Vivienne. (2007), “Historical Interpretation, Intentionalism and Philosophy of Mind". Journal of the Philosophy of History, vol. 1, no 1, pp. 25-62.

COLLINGWOOD, Robin. G. (s/d), A Idéia de História. Lisboa, Presença.

DERRIDA, Jacques. (1967), De la Grammatologie. Paris, Minuit.

DIGGINS, John Patrick. (1984), “The Oyster and the Pearl: The Problem of Contextualism in the Intellectual History. History and Theory, vol. 23, pp. 151-169.

DUNN, John. (1968), "The Identity of the History of Ideas". Philosophy, vol. XLIII, no 134, pp. 85-104.

EDLING, Max e MORKENSTAM, Ulf. (1995), “Quentin Skinner: From Historian to Political Scientist". Scandinavian Political Studies, vol. 18, pp. 119-132.

FEMIA, Joseph. (1988), “An Historicist Critique of 'Revisionist' Methods for Studying the History of Ideas, in J. Tully (ed.), Meaning and Context: Quentin Skinner and his Critics. Cambridge, Polity Press.

FERES JR., João. (2005), “De Cambridge para o Mundo, Historicamente: Revendo a Contribuição Metodológica de Quentin Skinner". DADOS, vol. 48, no 3, pp. 655-680.

FOUCAULT, Michel. (1969), “Qu'est-ce qu'un Auteur". Bulletin de la Société Française de Philosophie, vol. LXIV.

GADAMER, Hans-Georg. (2004), Verdade e Método I (6a ed.). Petrópolis, RJ/Bragança Paulista, SP, Vozes/Editora da Universidade São Francisco.

GRAHAM, Keith. (1988), “How do Illocutionary Descriptions Explain?”, in J. Tully (ed.), Meaning and Context: Quentin Skinner and his Critics. Cambridge, Polity Press.

GUNNELL, John. (1982), “Interpretation and the History of Political Theory: Apology and Epistemology". American Political Science Review, vol. 76, pp. 317-327.

HARLAN, David. (1989), "Intellectual History and the Return of Literature". The American Historical Review, vol. 94, no 3, pp. 581-609.

HIRSCH, David. (1967), Validity in Interpretation. New Haven, Yale University Press. (1976), The Aims of Interpretation. Chicago, The University of Chicago Press.

HOLLIS, Martin. (1988), "Say it with Flowers", in J. Tully (ed.), Meaning and Context: Quentin Skinner and his Critics. Cambridge, Polity Press.

JANSSEN, Peter L. (1985). "Political Thought as Traditionary Action: The Critical Response to Skinner and Pocock". History and Theory, vol. 24, pp. 115-146.

JASMIN, Marcelo. (2005), “História dos Conceitos e Teoria Social e Política: Referências Preliminares". Revista Brasileira de Ciências Sociais, vol. 20, no 57, pp. 27-38. 


\section{Ricardo Silva}

JAY, Martin. (1993), "The Textual Approach to Intellectual History", in Force Fields: Between Intellectual History and Cultural Critique. London, Routledge.

JUHL, Peter. (1980), Interpretation: An Essay in the Philosophy of Literary Criticism. Princeton, Princeton University Press.

KEANE, John. (1988), "More Theses on the Philosophy of History", in J. Tully (ed.), Meaning and Context: Quentin Skinner and his Critics. Cambridge, Polity Press.

KELLEY, Donald (ed.). (1990), Intellectual History: Canon and Variations. Rochester/New York, University of Rochester Press.

KING, Preston. (1983), The Theory of Context and the Case of Hobbes", in P. King (ed.), The History of Ideas: An Introduction to Method. London, Croom Helm.

(1995), "Historical Contextualism: The New Historicism?". History of European Ideas, vol. 21, pp. 209-233.

LACAPRA, Dominick. (1982), "Rethinking Intellectual History and Reading Texts", in D. Lacapra e S. L. Kaplan (eds.), Modern European Intellectual History: Reappraisals and New Perspectives. Ithaca/London, Cornell University Press.

LAMB, Robert. (2004), “Quentin Skinner's 'Post-Modern' History of Ideas”. History, vol. 89, no 295, pp. 424-433.

LASLETT, Peter. (1960), "Introduction”, in John Locke, Two Treatises on Government. Cambridge, Cambridge University Press.

(ed.). (1956), Philosophy, Politics and Society. Oxford, Blackwell.

LESLIE, Margareth. (1970), “In Defense of Anachronism”. History and Theory, vol. 18, pp. 433-447.

LOCKYER, Andrew. (1979), "'Traditions'” as Context in the History of Political Theory". Political Studies, vol. 2, pp. 201-217.

MANDELL, David Paul. (2000), “The History of Political Thought as a 'Vocation': A Pragmatist Defense", in J. Frank e J. Tambornino (eds.), Vocations of Political Theory. Minneapolis, The University of Minnesota Press.

MINOGUE, Kenneth. (1988), “Method in Intellectual History: Quentin Skinner Foundations", in J. Tully (ed.), Meaning and Context: Quentin Skinner and his Critics. Cambridge, Polity Press.

PALONEN, Kari. (2002), The History of Concepts as a Style of Political Theorizing: Quentin Skinner and Reinhart Koselleck's Subversion of Normative Political Theory". European Journal of Political Theory, vol. 1, pp. 91-106.

(2003), Quentin Skinner: History, Politics, Rhetoric. Cambridge, Polity Press.

PAREKH, Bhikhu e BERKI, Robert. (1973), "The History of Political Ideas: A Critique of Quentin Skinner Methodology". Journal of History of Ideas, vol. XXXIV, pp. 163-184.

PERREAU-SAUSSINE, Emile. (2007), "Quentin Skinner in Context". The Review of Politics, vol. 69, no 1, pp. 106-122.

POCOCK, John. (1962), “The History of Political Thought: A Methodological Enquiry", in P. Laslett e W. G. Runciman (eds.), Philosophy, Politics and Society (second series). Oxford, Blackwell, pp. 183-202. 


\section{O Contextualismo Linguístico na História do Pensamento Político...}

. (1972), Politics, Language and Time. London, Methuen.

. (2003), Linguagens do Ideário Político. São Paulo, Edusp.

(2004), "Quentin Skinner: The History of Politics and the Politics of History".

Common Knowledge, vol. 10, no 3, pp. 532-550.

RICOUER, Paul. (1979), “The Model of the Text: Meaningful Action Considered as a Text", in P. Rabinow e W. Sullivan (eds.), Interpretive Social Science: A Reader. Berkeley, University of California Press.

ROGERS, Ben. (1990), "Philosophy for Historians: The Methodological Writings of Quentin Skinner. History, vol. LXXV, pp. 262-271.

ROSEBURY, Brian. (1997), "Irrecoverable Intention and Literary Interpretation". British Journal of Aesthetics, vol. 37, pp. 219-230.

RUNCIMAN, David. (2001), "History of Political Thought: The State of Discipline". British Journal of Politics and International Relations, vol. 3, no 1, pp. 84-104.

SCOTT, Joan e KEATES, Debra. (2001), Schools of Thought: Twenty-five Years of Interpretive Social Science. Princeton, Princeton University Press.

SEIDMAN, Steven. (1983), "Beyond Presentism and Historicism: Understanding the History of Social Sciences". Sociological Inquiry, vol. 53, no 1, pp. 77-94.

SHAPIRO, Ian. (1982), "Realism in the Study of the History of Ideas". History of Political Thought, vol. III, pp. 535-578.

SILVA, Ricardo. (2008), "Liberdade e Lei no Neo-Republicanismo de Skinner e Pettit". Lua Nova, no 74, pp. 151-194.

SKINNER, Quentin. (1966), "The Limits of Historical Explanation". Philosophy, vol. 41, pp. 199-215.

. (1969), "Meaning and Understanding in the History of Ideas". History and Theory, vol. 8, no 3, pp. 3-53.

. (1970), "Conventions and the Understanding of Speech Acts". The Philosophical Quarterly, vol. 20, no 79, pp. 118-138.

(1971), "On Performing and Explaining Linguistic Actions". The Philosophical Quarterly, vol. 21, pp. 1-21.

. (1972), "Motives, Intentions and Interpretation of Texts". New Literary History, vol. 3, no 2, pp. 393-408.

. (1974), "Some Problems in the Analysis of Political Thought and Action". Political Theory, vol. 2, no 3, pp. 277-303.

. (1975), "Hermeneutics and the Role of History". New Literary History, vol. 8, pp. 209-232.

. (1983), “Machiavelli on the Maintenance of Liberty". Politics, vol. 18, pp. 3-15.

(1984), "The Idea of Negative Liberty", in R. Rorty, J. Schneewind e Q. Skinner (eds.), Philosophy in History. Cambridge, Cambridge University Press.

(1988a), "Social Meaning and the Explanation of Social Action", in J. Tully (ed.), Meaning and Context: Quentin Skinner and his Critics. Cambridge, Polity Press. 


\section{Ricardo Silva}

. (1988b), "A Reply to my Critics", in J. Tully (ed.), Meaning and Context: Quentin Skinner and his Critics. Cambridge, Polity Press.

_. (1988c), Maquiavel. São Paulo, Brasiliense.

. (1996), As Fundações do Pensamento Político Moderno. São Paulo, Companhia das Letras.

. (1997), “An Interview with Quentin Skinner". Cogito, vol. 11, pp. 69-76.

. (1999a), Liberdade Antes do Liberalismo. São Paulo, Ed. Unesp.

. (1999b), Razão e Retórica na Filosofia de Hobbes. São Paulo, Ed. Unesp.

. (2001), "The Rise of, Challenge to and Prospects for a Collingwoodian Approach to the History of Political Thought", in D. Castiglione e I. Hampsher-Monk (eds.), The History of Political Thought in National Context. Cambridge, Cambridge University Press.

. (2002a), Visions of Politics, vol. 1 - Regarding Method. Cambridge, Cambridge University Press.

. (2002b), “Quentin Skinner (interview)”, in M. L. Pallares-Burke (ed.), The New History. Cambridge, Polity Press.

_ (2005), Visões da Política: Sobre os Métodos Históricos. Algés, Difel.

(2007), "Intellectual History, Liberty and Republicanism: An Interview with Quentin Skinner". Contributions to the History of Concepts, vol. 3, no 1, pp. 103-123.

STRAWSON, Peter. (1964), "Intention and Convention in Speech Acts". Philosophical Review, vol. 73 , pp. 430-460.

TARLTON, Charles. (1973), "Historicity, Meaning and Revisionism in the Study of Political Thought". History and Theory, vol. 12, pp. 307-328.

TAYLOR, Charles. (1988), "The Hermeneutics of Conflict", in J. Tully (ed.), Meaning and Context: Quentin Skinner and his Critics. Cambridge, Polity Press.

TULLY, James. (1988), “The Pen is a Mighty Sword: Quentin Skinner Analysis of Politics", in J. Tully (ed.), Meaning and Context: Quentin Skinner and his Critics. Cambridge, Polity Press.

TURNER, Steven. (1983), "'Contextualism' and the Interpretation of the Classical Sociological Texts". Knowledge and Society, vol. 4, pp. 273-291.

URBINATI, Nadia. (2005), “The Historian and the Ideologist". Political Theory, vol. 33, pp. 89-95.

WEBER, M. (1992), Metodologia das Ciências Sociais. Campinas, SP, Ed. da Unicamp/Cortez.

WIMSATT, William e BEARDSLEY, Monroe. (1954), "The Intentional Fallacy", in W. Wimsatt (ed.), The Verbal Icon: Studies in the Meaning of Poetry. Lexington, University of Kentucky Press.

WITTGENSTEIN, Ludwig. (1958), Philosophical Investigations. Oxford, Basil Blackwell. 


\section{ABSTRACT \\ Linguistic Contextualism in the History of Politic Thought: Quentin Skinner and the Contemporary Methodological Debate}

This article aims to map and investigate the methodological debate spearheaded by the Cambridge School of history of political thought in the last four decades, focusing on the formulations of Quentin Skinner and the main objections raised by his critics. After a brief presentation of the prescriptions in Skinner's methods, the article discusses how his linguistic contextualism has been criticized for: a) his epistemological commitments (denounced alternately as relativist and positivist); b) his adherence to intentionalism; and c) his tendency towards "antiquarianism". The article concludes that of these three modalities of objections, the attribution of "antiquarianism" was the one that most compromised Skinner's original methodological formulations, recently leading him to virtually abandon his original antipresentist thrust.

Key words: Cambridge School; linguistic contextualism; Quentin Skinner; presentism; historicism

\section{RÉSUMÉ}

Le Contextualisme Linguistique dans l'Histoire de la Pensée Politique:

Quentin Skinner et le Débat Méthodologique Contemporain

Dans cet article, on souhaite situer et examiner le débat méthodologique proposé par l'École de Cambridge au sujet de l'histoire de la pensée politique dans les quatre dernières décennies, tout en insistant sur les positions de Quentin Skinner et les principales objections soulevées par ses critiques. Après une rapide présentation des prescriptions méthodologiques de Skinner, on voit que son contextualisme linguistique a reçu plusieurs critiques: a) par ses choix épistémologiques (dénoncés comme relativistes, ou encore positivistes); b) par son adhésion à l'intentionalisme; et c) par sa tendance à "l'ancien". On conclut que, parmi ces trois types d'objections, c'est l'attribution "d'ancien" qui a le plus nui aux formulations méthodologiques originales de Skinner, le menant récemment au virtuel abandon de son ardeur anti-présent initiale.

Mots-clé: École de Cambridge; contextualisme linguistique; Quentin Skinner; présentisme; historicisme 